\title{
"Transformational leadership and change readiness and a moderating role of perceived bureaucratic structure: an empirical investigation"
}

AUTHORS

ARTICLE INFO

DOI

RELEASED ON

LICENSE

JOURNAL

ISSN PRINT

ISSN ONLINE

PUBLISHER

FOUNDER

\section{Badri Abbasi}

Badri Abbasi (2017). Transformational leadership and change readiness and a moderating role of perceived bureaucratic structure: an empirical investigation. Problems and Perspectives in Management, 15(1), 35-44. doi:10.21511/ppm.15(1).2017.03

http://dx.doi.org/10.21511/ppm.15(1).2017.03

Tuesday, 28 March 2017

\section{$(c)$ EY-No}

This work is licensed under a Creative Commons Attribution-NonCommercial 4.0 International License

"Problems and Perspectives in Management"

LLC "Consulting Publishing Company "Business Perspectives"

LLC "Consulting Publishing Company "Business Perspectives"

NUMBER OF REFERENCES

28
NUMBER OF FIGURES

4
NUMBER OF TABLES

8

(C) The author(s) 2023. This publication is an open access article. 


\title{
Transformational leadership and change readiness and a moderating role of perceived bureaucratic structure: an empirical investigation
}

\begin{abstract}
The purpose of this study was to examine the relationship between transformational leadership and change readiness through perceived bureaucratic structure among government employees in Rasht. As a methodology, descriptive method was applied using questionnaire to collect data. The studied population consisted of 600 employees from three state organizations including Municipality, Gilan Tax Department and Gilan Justice Court. According to Morgan table, the sample size was estimated at 234. This study examined six hypotheses, which were tested using multiple regression method. The results showed that transformational leadership had a positive direct effect on employee change readiness and its dimensions. However, substitution of the bureaucratic structure in the model eliminated the effect. Finally, the hypothesis on the effect of transformational leadership on change readiness through perceived bureaucratic structure was rejected.
\end{abstract}

Keywords: transformational leadership, perceived bureaucratic structure, employee change readiness, emergent change readiness, planned change readiness.

JEL Classification: M12, D73.

\section{Introduction}

Organizational change is the process of transformation in attitudes, structures, policies or outputs of some departments (Chaghari et al., 2012). Currently, scholars are unanimous on the fact that organizational transformation is a planned change, which takes place in the context of the organization (Malhotra and Hinings, 2015; Holloway, 2015; Thistle and Molinaro, 2016). Moreover, sources of change play a vital role in making changes and, more importantly, in organizational change readiness. In organizations, leaders are the source of change readiness (Mousavi, 2005).

Change readiness refers to understanding of the required changes in general structures and processes of the organizations for better implementation of operations. In this case, change management vision refers to the content and effects of organizational changes in the public sector or at the national level. Based on willingness of employees, change readiness can be classified into planned and emergent change. Planned change is through a top-down rational process, while the immediate change requires strong organizational readiness to implement the changes bottom up (Van der Voet, 2014; Kickert, 2010).

Although change readiness has become an institutional mission in government agencies, no change has been made in structures yet. There is a conflict between organizational missions and the current structures. Thus, the conflict perceived by employees discourages change readiness; the existing bureaucratic structure prevents the effectiveness of transformational leader-

(C) Badri Abbasi, 2017.

Badri Abbasi, Department of Business Management, Rasht Branch, Islamic Azad University, Rasht, Iran.

This is an Open Access article, distributed under the terms of the Creative Commons Attribution-NonCommercial 4.0 International license, which permits re-use, distribution, and reproduction, provided the materials aren't used for commercial purposes and the original work is properly cited. ship. New organizational goals may not be achieved when there is no change readiness; thus, this will take years and organizations do not progress in the competitive world. On the other hand, organizations can play their roles well when they have active, pro+ductive, capable, creative and effective human resources. Bureaucratic structure is a main barrier for activity of the people and, consequently, the organization, followed by the entire society and will impose irreversible damages to the society in the long term. Therefore, the focus of this study is the relationship between transformational leadership and change readiness considering the perceived bureaucratic structure.

\section{Literature review}

All managers agree that effective changes along with positive attitude are important features of administrative systems. This is not specific to a particular organization or institution; all administrative, social and state organizations, institutions and agencies should attempt to implement effective changes and reform the procedures commensurate with current conditions (Raeeisi, 2006). In making organizational change, it is important that employees embrace the changes. To embrace and internalize the changes as an element of behavioral and personal structure of employees, it is first required to provide the needed readiness in employees and make them ready for change. Change readiness of employees is associated with characteristics, which they perceive during interactions with factors and organizational phenomena (Soltani, 2005).

Although some researchers believe that the context of government agencies is inconsistent with change mechanisms, it is controversial whether the change and its effectiveness must necessarily follow an organizational nature, because change is associated with vital consequences for the organization. This is especially true for government agencies with relatively static nature. The question is whether the organizational change can be managed effectively in the public sec- 
tor, how changes can be managed in government organizations by the least conflict (Van der Voet, 2014). In the process of making and instituting change and positive attitude to government agencies, three perspectives are generally considered. The first group analyzes abilities of managers to overcome organizational inertia and make organizational changes successfully. Others focus on discovery of the relationship between demographic variables of managers. The third group evaluates the subjective models of managers (Rahmanseresht \& Moghaddam, 2007). In fact, most studies point out to the concept and content of change rather than its process. Studies have critically addressed the organizational change and the concept of change readiness using two approaches: planned change readiness and emergent change readiness. The significance of these two approaches challenges their application in public and private organizations. In addition to the growing significance of change readiness as the main factor of organizational transformation, its underlying factors should also be taken into consideration.

In addition to transformation, which refers to ability and attitude of top and middle managers in embracing organizational change and explaining it to subordinates, change depends on the organizational context. Considering the above factors, organizational change control is an effort to improve the organization (Frazja \& Khademi, 2012). Government agencies generally operate under strict legal framework and face with a growing demand for accountability. This is why government agencies tend to avoid risk, formal operation and concentrated decisions. Accordingly, structure of government agencies is bureaucratic. Organizational structure is important as a determinant of organizational change. Despite transformational attitudes, effect of transformation on positive change readiness will change when there is a strong assumption in the presence of strict change structures. Isett et al. (2012) have argued that government agencies with perceived bureaucratic structure may have changed management tolerance; however, little empirical evidence confirms this (Van der Voet, 2014; Van der Voet et al., 2016).

Obviously, positive change is vital, because future needs change. Successful organizations incorporate change within their organizational framework. Clearly, any organization is founded to meet needs. Since human needs are constantly changing or shifting to new needs, organizations are always required to change. The need for change management is now more vivid (Tseng, 2010; Russ, 2008). In fact, organizations are a key element of social communities. Management and leadership are the most important indicators of survival, dynamism, growth and even destruction (Gill, 2010). Diverse advances in science and technology have changed the traditional structure of management; organizational change has replaced traditional management by dynamic management. In addition to their traditional task, which is the realization of ultimate organizational goals, organizations need to respond and be receptive to demands and criticisms of internal and external societies (Burnes, 2011).

Transformational leadership is the most basic element of successful or failed transformation program. Transformational strategies are those techniques and patterns, which practically cause changes in various fields (Pawar, 2003; Pearce et al., 2003; Robbins, 2002). Managers who use transformational leadership style motivate members through dimensions of leadership, which can be ideal effects of inspirational motivation and rational stimulation (Jalilian et al., 2010). Therefore, transformational leadership and its dimensions contribute to change readiness. Planned changes and emergent changes are evaluated as a means of measuring success or failure of an organization to achieve its goals. In fact, one of the factors, which can hinder effectiveness of transformational leadership is the structure of government organizations. In bureaucratic organizations, administrative tasks are distributed within the organizational hierarchy. This structure is governed by a formal system of regulations on activities and decisions of employees (Nabavi et al., 2013).

In a bureaucratic organization, the regulations may be used for interests of people who work in that organization. This system is adapted to business and technological needs. Dimock (1994) defined the concept of bureaucracy as anti-mobility and anti-innovation in the organization. According to Dimock, bureaucracy is a fundamental combination, which tends to inflexibility and destruction of a sense of character. Theorists who have argued bureaucracy rationally have realized problems such as delays at works and paperwork, which may appear reasonable for the organization; noting inefficiency of the organization, they believe that bureaucratic structure slows down the process of organizational change.

\section{Objectives}

1. To evaluate the effect of transformational leadership on change readiness of government employees.

1.1. To evaluate the effect of transformational leadership on planned change readiness of government employees.

1.2. To evaluate the effect of transformational leadership on emergent change readiness of government employees.

2. To evaluate the effect of transformational leadership on change readiness of government employees through the perceived bureaucratic structure.

2.1. To evaluate the effect of transformational leadership on planned change readiness of government employees through the perceived bureaucratic structure.

2.2. To evaluate the effect of transformational leadership on emergent change readiness of government employees through the perceived bureaucratic structure. 


\section{Theoretical framework}

Theoretical framework is a basis on which the study relies. It is a logical, developed, described and perfected network between variables characterized through processes such as interviews, observation and literature review. These variables are associated with the studied problem. A well-established theoretical framework identifies important variables of a defined problem and describes the relationships between variables logically.

The dependent variable in this study is change readiness. According to Linstone and Mitroff (1994), three factors are effective on organizational change readiness: personal, organizational and technological. Personal factors are the most difficult and most important factors. Juechter et al. (1998) assert that organizational change readiness is required to challenge and clear beliefs, assumptions, attitudes of individuals. Van der Voet (2014) believes that both planned and emergent change readiness are effective way to make change in the bureaucratic structure.

The independent variable is transformational leadership. Brnez believes that transformational leaders have vision and change their followers to do extraordinary things, both in emergent change planning and in planned changes. According to Brnez, transformational leaders are able to draw the required paths for new organizations, because they are the source of change and fully dominant on the changes. According to Brnez, transformational leadership is applicable by everyone, in every organization and to any situation. According to Shamir et al. (1993), transformational leaders increase efficiency of their employees by their ability to organize and increase the skills required. Van der Voet (2014) states that lower or higher degree of transformational leadership provides the same support for employees in planned processes. Moreover, the role of transformational leadership is more effective at the highest levels of management.

The moderating variable in this study is the perceived organizational structure. According to literature, this variable influences the relationship between dependent and independent variables and has a separate variance to explain its variations. Veber believes that bureaucratic characteristics are important factors of work alienation. Because bureaucracy has different characteristics, different characteristics of bureaucratic structure can be expected to influence work alienation differently. Van der Voet (2014) claims that transformational leadership behaviors of direct supervisors slightly contribute to change through planned process, while the role of emergent process is very important, but in a non-bureaucratic structure. In fact, bureaucratic structure interrupts the effectiveness of emergent process.

Theoretical framework of this study, which is derived from the model of Van der Voet (2014) reflects the governing relations on independent and dependent variables based on literature. The conceptual model is shown in Figure 1.

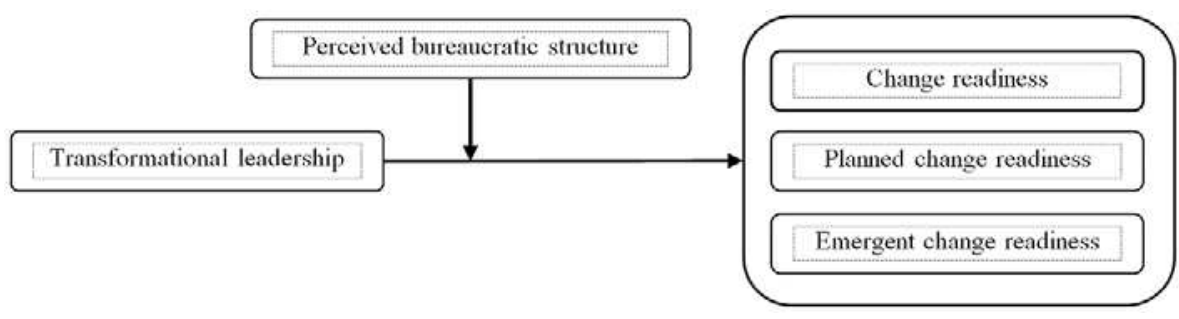

Fig. 1. Conceptual framework

\section{Hypotheses}

Hypothesis 1: Transformational leadership is effective on change readiness of government employees.

1.1. Transformational leadership is effective on planned change readiness.

1.2. Transformational leadership is effective on emergent change readiness.

Hypothesis 2: Transformational leadership is effective on change readiness of government employees through perceived bureaucratic structure.

2.1. Transformational leadership is effective on planned change readiness of government employees through perceived bureaucratic structure.

2.2. Transformational leadership is effective on emergent change readiness of government employees through perceived bureaucratic structure.

\section{Materials and methods}

Method shows how to progress toward an objective. Research involves a series of activities, which are properly thought and carefully come into force. It also includes the processes of search, review, test and experiment. These processes should be regular, careful, critical, objective and reasonable. The end result is discovery of new facts, which will help us to deal with the problem. Research methodologies in behavioral sciences can be categorized based on two important dimensions: A) purpose, B) data collection.

Accordingly, this study is an applied research and uses a descriptive correlational method for data collection. Applied research acquires the knowledge or understanding required to determine the instrument by which a particular need is met. 
Descriptive research describes and interprets the things already exist; it is concerned with existing conditions or relations, common beliefs, ongoing processes, vivid effects or developing trends. Correlational research is a type of descriptive research. The main goal in correlational research is to determine whether a relationship exists between two or more quantitative (measurable) variables and to what extent, if so.

The studied population included 600 employees of three government agencies in Rasht including $\mathrm{Mu}-$ nicipality (284), Gilan Tax Department (124) and Gilan Justice Court (192). Based on Morgan table, the sample size was estimated at 234. These agencies were selected for their cooperation in conducting the present study. A convenient sampling method was used, in which a group of members of the studied population are selected because of the ease of sampling (Table 1).

Table 1. Distribution of samples in organizations

\begin{tabular}{|l|c|c|}
\hline \multicolumn{1}{|c|}{ Organizations } & Population & Sample \\
\hline Municipality & 284 & 113 \\
\hline Tax Department & 124 & 48 \\
\hline Justice Court & 193 & 76 \\
\hline Total & 600 & 236 \\
\hline
\end{tabular}

5.1. Validity of questionnaire. Validity determines whether the measurement tool can measure the trait for which it is designed. Validity is important, because incorrect measurements can make any scientific research invalid. There are several ways to measure validity. This study used content validity to measure validity of the questionnaire. For this purpose, relevant experts and professors were asked to provide their opinions. By applying these opinions and making required modifications, content validity of the questionnaire was confirmed. Based on available textbooks regarding methodology, the questionnaire was purposeful, short and easy to respond, with adequate guideline. A brief introduction was available at the beginning of the questionnaire; moreover, oral explanations were considered to simplify the questions during data collection.

5.2. Construct validity of questionnaire. This section presents the results of measurement model. Table 2 shows the factor loading for all research variables. Figures 2, 3, 4 show the obtained results of LISREL Software for confirmatory factor analysis. Confirmatory factor analysis shows significant positive correlation between all the observed variables and latent variables.

Table 2. The results of confirmatory factor analysis

\begin{tabular}{|c|c|c|c|c|c|c|c|}
\hline \multicolumn{2}{|r|}{ Variable } & Observer variable & Factor loading & \multicolumn{2}{|c|}{ Variable } & Observer variable & Factor loading \\
\hline \multirow{11}{*}{ 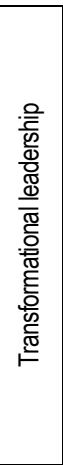 } & \multirow{3}{*}{ Supervisor expression } & $\underline{X 1}$ & 0.69 & \multirow{3}{*}{\multicolumn{2}{|c|}{ High-performance expected }} & X11 & 0.68 \\
\hline & & $\underline{X 2}$ & 0.74 & & & $\mathrm{X} 12$ & $\underline{0.73}$ \\
\hline & & $\underline{\underline{X}}$ & 0.67 & & & $\mathrm{X} 13$ & $\underline{0.75}$ \\
\hline & \multirow{3}{*}{ Intellectual Model } & $\overline{X 4}$ & 0.83 & \multirow{4}{*}{\multicolumn{2}{|c|}{ Employee support }} & $\mathrm{X} 14$ & $\overline{0.72}$ \\
\hline & & $\mathrm{X} 5$ & 0.83 & & & $\mathrm{X} 15$ & $\underline{0.78}$ \\
\hline & & $\mathrm{X} 6$ & 0.79 & & & $\mathrm{X} 16$ & $\overline{0.81}$ \\
\hline & \multirow{5}{*}{ Encouraged embracement of goals } & $\mathrm{X} 7$ & 0.88 & & & $\mathrm{X} 17$ & $\underline{0.62}$ \\
\hline & & $\mathrm{X} 8$ & 0.91 & \multirow{4}{*}{\multicolumn{2}{|c|}{ Intellectual stimulation }} & $\mathrm{X} 18$ & $\overline{0.74}$ \\
\hline & & X9 & 0.85 & & & $\mathrm{X} 19$ & $\underline{0.69}$ \\
\hline & & \multirow{2}{*}{$\mathrm{X} 10$} & \multirow{2}{*}{0.78} & & & $\mathrm{X} 20$ & $\underline{0.73}$ \\
\hline & & & & & & $\mathrm{X} 21$ & 0.77 \\
\hline \multirow{12}{*}{ 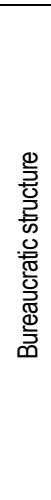 } & \multirow{5}{*}{ Concentration } & $\mathrm{X} 1$ & 0.65 & \multirow{6}{*}{\multicolumn{2}{|c|}{ Planned changes }} & $\mathrm{X} 1$ & 0.59 \\
\hline & & $\mathrm{X} 2$ & 0.58 & & & $\mathrm{X} 2$ & 0.72 \\
\hline & & $\mathrm{X} 3$ & 0.72 & & & $\mathrm{X} 3$ & 0.68 \\
\hline & & $\mathrm{X} 4$ & 0.73 & & & $\mathrm{X} 4$ & 0.56 \\
\hline & & $\mathrm{X} 5$ & 0.75 & & & $\mathrm{X} 5$ & 0.81 \\
\hline & \multirow{7}{*}{ Formalization } & $\mathrm{X} 6$ & 0.60 & & & $\mathrm{X} 6$ & 0.77 \\
\hline & & $\mathrm{X} 7$ & 0.70 & $\frac{\omega}{d}$ & \multirow{6}{*}{ Emergent changes } & $\mathrm{X} 7$ & 0.74 \\
\hline & & $\mathrm{X} 8$ & 056 & $\frac{\sqrt{\pi}}{0}$ & & $\mathrm{X} 8$ & 0.72 \\
\hline & & $\times 9$ & 0.74 & & & $\mathrm{X9}$ & 0.69 \\
\hline & & $\mathrm{X} 10$ & 0.58 & & & $\mathrm{X} 10$ & 0.56 \\
\hline & & $\mathrm{X} 11$ & 0.64 & & & $\mathrm{X} 11$ & 0.55 \\
\hline & & $\mathrm{X} 12$ & 0.53 & & & & \\
\hline
\end{tabular}




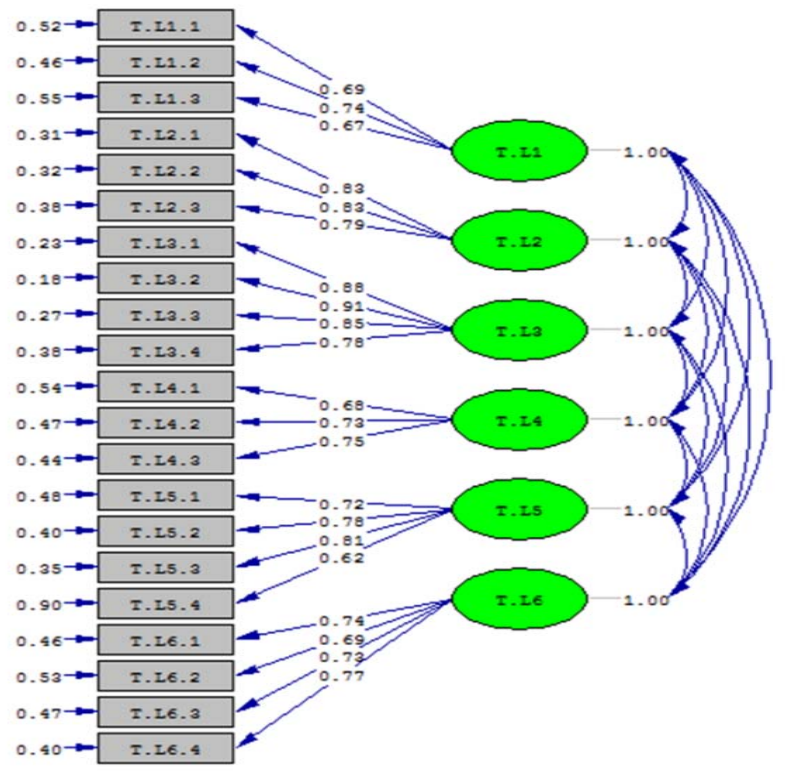

are $=395.95, d f=174, P-v a l u e=0.00000, R M S E A=0.081$

Fig. 2. Confirmatory factor analysis for transformational leadership

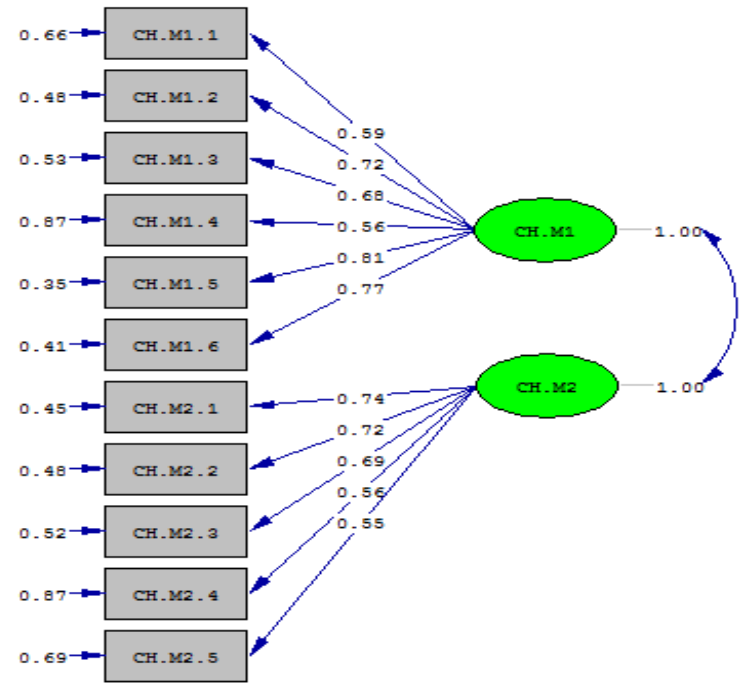

Chi-Square $=106.78, d f=43, P-$ value $=0.00000$, RMSEA $=0.088$

Fig. 3. Confirmatory factor analysis for change readiness

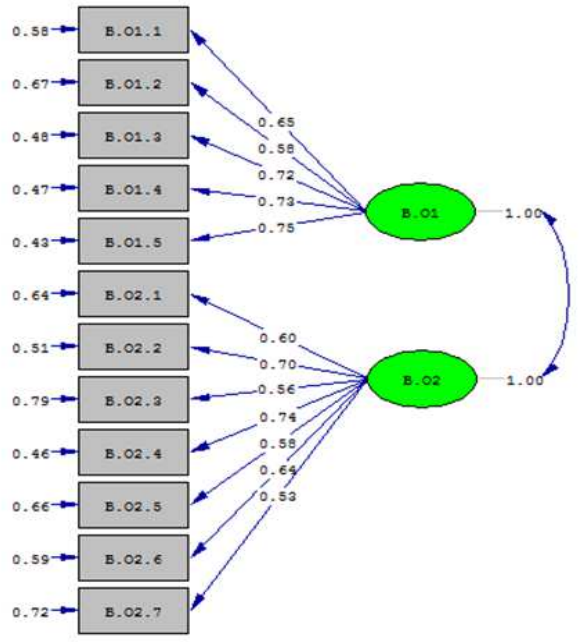

Chi-Square $=154.72, d f=53, p-$ value $=0.00000$, RMSEA $=0.093$

Fig. 4 Confirmatory factor analysis for bureaucratic structure 
5.3. Reliability of questionnaire. Reliability determines whether a measurement tool developed to measure a variables or trait can provide similar results under similar conditions in another time or place. In other words, a reliable tool is repeatable and provides similar results. Cronbach's Alpha can be considered as a good indicator for validity and internal consistency. In this way, reliability is usually considered low if $\alpha<0.60$, reasonable if $\alpha=0.70$ and good if $\alpha>0.80$. Table 3 reports the Cronbach's Alpha obtained for variables (Table 3 ).

Table 3. Cronbach's Alpha

\begin{tabular}{|l|c|c|}
\hline \multicolumn{1}{|c|}{ Variable } & Number of questions & Alpha \\
\hline Transformational leadership & 21 & 0.911 \\
\hline Change readiness & 11 & 0.921 \\
\hline Bureaucratic structure & 12 & 0.759 \\
\hline
\end{tabular}

The obtained Cronbach's Alpha indicates good reliability of the questionnaire.

\section{Data analysis}

In this study, the data collected were presented in the form of descriptive and inferential statistics using two software SPSS19 and LISREL 8. The descriptive statistics including distribution of samples in terms of demographic variables (gender, age, education, and work experience) and dependent and independent variables were presented by mean, standard deviation, variance and frequency. Using structural equations modelling, hypotheses were tested in inferential statistics.

Table 4. Demographics of respondents

\begin{tabular}{|l|l|l|l|l|l|}
\hline \multicolumn{2}{|c|}{ Gender } & \multicolumn{3}{c|}{ Age } \\
\hline & Frequency & $\%$ & & Frequency & $\%$ \\
\hline
\end{tabular}

\begin{tabular}{|c|c|c|c|c|c|}
\hline Female & 97 & 41.1 & $20-30$ & 73 & 30.9 \\
\hline Male & 134 & 56.8 & $31-40$ & 122 & 51.7 \\
\hline Total & 231 & 97.9 & $41-50$ & 39 & 16.5 \\
\hline Unknown & 5 & 2.1 & $>50$ & 2 & 0.8 \\
\hline Total & 236 & 100 & Total & 236 & 100 \\
\hline \multicolumn{3}{|c|}{ Education } & \multicolumn{3}{|c|}{ Experience } \\
\hline High school diploma & 11 & 4.7 & $<5$ & 76 & 32.2 \\
\hline Associate degree & 61 & 25.8 & $50-10$ & 66 & 28 \\
\hline Undergraduate & 111 & 47 & 10-15 & 51 & 21.6 \\
\hline Postgraduate & 49 & 20.8 & $15-20$ & 22 & 9.3 \\
\hline $\mathrm{PhD}$ & 4 & 1.7 & $>20$ & 19 & 8.1 \\
\hline Total & 236 & 100 & Total & 234 & 99.2 \\
\hline \multicolumn{3}{|c|}{ Employment } & Unknown & & 0.8 \\
\hline Official & 97 & 41.1 & & & \\
\hline Experimental & 22 & 9.3 & & & \\
\hline Contractual & 71 & 30.1 & & & \\
\hline Pact & 46 & 19.5 & & & \\
\hline Total & 236 & 100 & & & \\
\hline
\end{tabular}

As shown in Table 4, 41.1\% of respondents were female, $56.8 \%$ were male and gender of $2.1 \%$ was unknown. The age groups included people aged 20-30 $(30.9 \%), 31-40(51.7 \%), 41-50(16.5 \%)$ and older than $50(0.8 \%)$. Educational level of respondent ranged from high school diploma (4.7\%), associate degree $(25.8 \%)$, undergraduate $(47 \%)$, and postgraduate $(20.8 \%)$ to $\mathrm{PhD}(1.7 \%)$. Work experience of respondents ranged from less than 5 years $(32.2 \%), 5-10$ years (28\%), $10-15$ years $(21.6 \%), 15-20$ years $(9.3 \%)$ to more than 20 years $(8.1 \%)$. Moreover, $0.8 \%$ of respondents did not answer this question. Employment of respondents was official $(41.1 \%)$, experimental $(9.3 \%)$, contractual (30.1\%) and pact (19.5\%).

6.1. Description of variables. Before data analysis, it is essential to describe the variables. In this regard, the variables are descriptively reported in Table 5.

Table 5. Descriptive study

\begin{tabular}{|l|c|c|c|c|c|c|}
\hline \multicolumn{1}{|c|}{ Descriptive statistics } & Number & Minimum & Maximum & Mean & Standard deviation & Variance \\
\hline Transformational Leadership & 236 & 1.57 & 5 & 3.4019 & 0.62525 & 0.391 \\
\hline Supervisor expression & 236 & 1.33 & 5 & 3.3715 & 0.79476 & 0.632 \\
\hline Intellectual Model & 236 & 1 & 5 & 3.3743 & 0.91518 & 0.838 \\
\hline Encouraged embracement of goals & 236 & 1 & 5 & 3.3955 & 0.85991 & 0.739 \\
\hline High-performance expected & 236 & 1.67 & 5 & 3.8242 & 0.74092 & 0.549 \\
\hline Employee support & 236 & 1 & 5 & 3.2574 & 0.76749 & 0.589 \\
\hline Intellectual stimulation & 236 & 1 & 5 & 3.1882 & 0.78240 & 0.612 \\
\hline Change readiness & 236 & 1.88 & 5 & 3.3793 & 0.57929 & 0.332 \\
\hline Planned changes & 236 & 2 & 5 & 3.4374 & 0.56753 & 0.322 \\
\hline Emergent changes & 236 & 1.4 & 5 & 3.3212 & 0.69145 & 0.478 \\
\hline Bureaucratic structure & 236 & 1.76 & 4.71 & 3.3768 & 0.50458 & 0.255 \\
\hline Concentration & 236 & 1 & 5 & 3.6572 & 0.65098 & 0.424 \\
\hline Formalization & 236 & 1.71 & 5 & 3.1007 & 0.63800 & 0.407 \\
\hline
\end{tabular}

\subsection{Dimensions of transformational leadership.}

- Table 4 reports minimum value (1.57), maximum value (5), mean (3.4019), standard deviation $(0.62525)$ and variance $(0.391)$ for transformational leadership.
- Table 5 reports minimum value (1.33), maximum value (5), mean (3.3715), standard deviation (0.79476) and variance (0.632) for supervisor expression.

- Table 5 reports minimum value (1), maximum value (5), mean (3.3743), standard deviation 
(0.91518) and variance (0.838) for intellectual model.

- Table 5 reports minimum value (1), maximum value (5), mean (3.3955), standard deviation $(0.85991)$ and variance $(0.739)$ for encouraged embracement of goals.

- Table 5 reports minimum value (1), maximum value (5), mean (3.8242), standard deviation $(0.74092)$ and variance $(0.549)$ for high performance expected.

- Table 5 reports minimum value (1), maximum value (5), mean (3.2574), standard deviation $(0.76749)$ and variance (0.589) for employee support.

- Table 5 reports minimum value (1), maximum value (5), mean (3.1882), standard deviation $(0.78240)$ and variance $(0.612)$ for intellectual stimulation.

According to Table 5, the lowest mean is related to intellectual stimulation and the highest mean belongs to high performance expected. In bureaucratic organizations, this high performance expected can prevent the effect of transformation on change readiness; that is, transformation is more prominent in highperformance expected.

\subsection{Dimensions of change readiness.}

- Table 5 reports minimum value (1.88), maximum value (5), mean (3.3793), standard deviation (0.57929) and variance (0.332) for change readiness. In addition, Table 4 shows dimensions of change readiness as follows:

- Table 5 reports minimum value (2), maximum value (5), mean (3.4374), standard deviation $(0.56753)$ and variance $(0.322)$ for planned change.

- Table 5 reports minimum value (1.4), maximum value (5), mean (3.3212), standard deviation (0.69145) and variance (0.478) for emergent change.

According to Table 5, the lowest mean is related to emergent change and the highest mean belongs to planned change.

\subsection{Dimensions of bureaucratic structure.}

- Table 5 reports minimum value (1.76), maximum value (4.71), mean (3.3768), standard deviation (0.50458) and variance $(0.255)$ for bureaucratic structure. In addition, Table 4 shows dimensions of bureaucratic structure as follows:

- Table 5 reports minimum value (1), maximum value (5), mean (3.6572), standard deviation $(0.65098)$ and variance $(0.424)$ for concentration.

- Table 5 reports minimum value (1.71), maximum value (5), mean (3.1007), standard deviation $(0.63800)$ and variance $(0.407)$ for formalization.
According to Table 5, the lowest mean is related to formalization and the highest mean belongs to concentration.

6.5. Normality tests. According to Table 6, sig $>0.05$ for K-S test of variables. Therefore, the variables are normally distributed.

Table 6. Kolmogorov-Smirnov test for variables

\begin{tabular}{|l|c|c|}
\hline & Test value & Sig. \\
\hline Bureaucratic structure & 1.302 & 0.067 \\
\hline Change readiness & 0.917 & 0.369 \\
\hline Transformational leadership & 0.626 & 0.828 \\
\hline
\end{tabular}

6.6. Hypotheses. Hypothesis 1: Transformational leadership is effective on change readiness of government employees. Regression analysis (Table 7) shows the extent of correlation (0.593) between transformational leadership and change readiness of government employees. Transformational leadership can explain change readiness by $35.2 \%$. Given the positive $\beta$, transformational leadership is positively and significantly effective on change readiness of government employees.

Table 7. Regression analysis

\begin{tabular}{|c|l|c|c|c|c|c|}
\hline & & $\mathrm{R}$ & $\mathrm{R}^{2}$ & $\beta$ & Sig. & Result \\
\hline 6.1 & $\begin{array}{l}\text { Transformational lead- } \\
\text { ership and change } \\
\text { readiness }\end{array}$ & 0.593 & 0.352 & +0.593 & 0.000 & Confirmed \\
\hline 6.2 & $\begin{array}{l}\text { Transformational lead- } \\
\text { ership and planned } \\
\text { change readiness }\end{array}$ & 0.526 & 0.277 & +0.526 & 0.000 & Confirmed \\
\hline 6.3 & $\begin{array}{l}\text { Transformational lead- } \\
\text { ership and emergent } \\
\text { change readiness }\end{array}$ & 0.557 & 0.310 & +0.557 & 0.000 & Confirmed \\
\hline
\end{tabular}

Hypothesis 1.1: Transformational leadership is effective on planned change readiness.

Regression analysis (Table 7) shows the extent of correlation (0.526) between transformational leadership and planned change readiness of employees. Transformational leadership can explain planned change readiness by $27.7 \%$. Given the positive $\beta$, transformational leadership is positively and significantly effective on planned change readiness of government employees.

Hypothesis 1.2: Transformational leadership is effective on emergent change readiness.

Regression analysis (Table 7) shows the extent of correlation (0.557) between transformational leadership and emergent change readiness of employees. Transformational leadership can explain emergent change readiness by $31 \%$. Given the positive $\beta$, transformational leadership is positively and significantly effective on emergent change readiness of government employees.

Hypothesis 2: Transformational leadership is effective on change readiness of government employees through perceived bureaucratic structure. 
As shown in Table 8, the linear regression model obtained is significant ( $\operatorname{sig}<0.05$ ); thus, there is a significant relationship (0.593) between transformational leadership and change readiness of employees. The second linear model is obtained by substitution of the variable bureaucratic structure. However, the hypothe- sis that transformational leadership is effective on change readiness of employees through the perceived bureaucratic structure is rejected, because sig $>0.05$. Moreover, Durbin-Watson value $=2.163$, which indicates no auto-correlation between residuals of the equation estimated.

Table 8. Multiple regression analysis of transformational leadership on employee change readiness through perceived bureaucratic structure

\begin{tabular}{|c|c|c|c|c|c|c|c|c|c|}
\hline & & & $R$ & $\mathrm{R}^{2}$ & Sig. & $R^{2}$ change & $\beta$ & $\beta$ Sig. & Durbin-Watson \\
\hline \multirow{3}{*}{1.7} & Model 1 & Transformational leadership & 0.593 & 0.352 & 0.000 & \multirow{3}{*}{0.005} & 0.593 & 0.000 & \multirow{3}{*}{1.859} \\
\hline & Model 2 & Transformational leadership & \multirow{2}{*}{0.598} & \multirow{2}{*}{0.357} & \multirow{2}{*}{0.000} & & 0.581 & 0.000 & \\
\hline & & Bureaucratic structure & & & & & -0.074 & 0.167 & \\
\hline \multirow{3}{*}{2.7} & Model 1 & Transformational leadership & 0.526 & 0.277 & 0.000 & \multirow{3}{*}{0.007} & 0.526 & 0.000 & \multirow{3}{*}{2.018} \\
\hline & Model 2 & Transformational leadership & \multirow{2}{*}{0.533} & \multirow{2}{*}{0.284} & \multirow{2}{*}{0.000} & & 0.513 & 0.000 & \\
\hline & & Bureaucratic structure & & & & & -0.084 & 0.135 & \\
\hline \multirow{3}{*}{3.7} & Model 1 & Transformational leadership & 0.577 & 0.310 & 0.000 & \multirow{3}{*}{0.003} & 0.557 & 0.000 & \multirow{3}{*}{1.747} \\
\hline & Model 2 & Transformational leadership & \multirow{2}{*}{0.313} & \multirow{2}{*}{0.559} & \multirow{2}{*}{0.000} & & 0.548 & 0.000 & \\
\hline & & Bureaucratic structure & & & & & -0.054 & 0.328 & \\
\hline
\end{tabular}

Hypothesis 2.1: transformational leadership is effective on planned change readiness through perceived bureaucratic structure.

As shown in Table 8, the linear regression model obtained is significant ( $\operatorname{sig}<0.05)$; thus, there is a significant relationship (0.526) between transformational leadership and planned change readiness of employees. The second linear model is obtained by substitution of the variable bureaucratic structure. However, the hypothesis that transformational leadership is effective on planned change readiness of employees through the perceived bureaucratic structure is rejected, because $\beta$ sig $>0.05$. Moreover, Durbin-Watson value $=2.018$, which indicates no auto-correlation between residuals of the equation estimated.

Hypothesis 2.2: transformational leadership is effective on emergent change readiness through perceived bureaucratic structure.

As shown in Table 8, the linear regression model obtained is significant ( $\mathrm{sig}<0.05)$; thus, there is a significant relationship (0.577) between transformational leadership and emergent change readiness of employees. The second linear model is obtained by substitution of the variable bureaucratic structure. However, the hypothesis that transformational leadership is effective on emergent change readiness of employees through the perceived bureaucratic structure is rejected, because sig $>0.05$. Moreover, Durbin-Watson value $=1.747$, which indicates no auto-correlation between residuals of the equation estimated.

\section{Conclusion}

As findings of this study show, transformational leadership is effective on planned and emergent change readiness. Accordingly, the following remarks are provided for organizations:
It is essential that managers increase the expected performance by regular evaluations and appropriate incentives to make planned changes. The method of choice in this type of planning is called hearts and minds method, which is a thorough effort for changing attitudes, values and beliefs of all employees. Through this normative method, the manager attracts employee commitment and creates a shared vision (Geijsel et al., 2003).

Managers should pay attention to personalities and personal needs of employees to manage their performance effectively.

Senior managers should support and encourage their employees in thinking about previous problems and solving them in new ways. In this respect, they can consider delegation of authority and encourage innovation.

Senior managers should promote knowledge of organizational goals based on greater interaction within work groups. This is called adaptive planning method, which is the division of power between employers and employees. Change requires negotiation, agreement and consensus resulting from regular interactions.

For intellectual stimulation of employees, managers can use creativity of employees in problem solving by holding regular meetings and using their suggested solutions. Managers can also reward people who use new methods.

To use intellectual models of employees, managers can raise questions to make employees think about their tasks, revise their routines and select the best solutions.

To control organizational crisis, managers need to form special work groups with short-term, long-term and mid-term planning skills. In emergent change planning, this is called navigator, that is, imposition of 
changes in critical situations or when other methods are useless. This results from managerial authority without consultation with other people.

This study also presents the following remarks for future works:

Consideration of other leadership styles including pragmatic leadership in the hypothesized relationships can provide more accurate results; therefore, it is proposed to test these styles in future works.

It is recommended to consider other categories of organizational structure and its dimensions such as organic and mechanical structure simultaneously in relationships and compare the results.

Structure of public and private organizations is different; government agencies follow both domestic and state laws. Therefore, future works are recommended to test above hypotheses in private organizations.

It is also recommended to consider effects of demographic variables on the studied relationships.
Personality can be measured as a mediating or confounding variable.

\section{Limitations}

This study only considered one leadership style (transformational leadership).

Despite diversity of organizational structure, this study only considered the bureaucratic structure as a moderator of the studied relationships.

The studied population included employees of government agencies (Gilan Tax Department, Gilan Justice Court and Municipality).

This study discarded the role of individual characteristics, including age, experience or gender in the studied relationships.

Due to time constraints and expensiveness of the study (long distances in the whole province), probability sampling was not practical for the study; therefore, convenient non-probability sampling was used.

\section{References}

1. Burnes, B. (2011). Introduction: Why does change fail, and what can we do about it? Journal of Change Management, 11 (4), pp. 445-450.

2. Chaghari, M., Tofighi, S., Amerian, A. \& Karimi-Zarchi, A. (2012). Different effects of organizational change and transformation on organizational health, Basij strategic studies, 15 (54), pp. 83-96.

3. Dhillon, G., Syed, R. \& Pedron, C. (2016). Interpreting information security culture: An organizational transformation case study, Computers \& Security, 56, pp. 63-69.

4. $\quad$ Dimock, M.E. (1944). Bureaucracy self-examined, Public Administration Review, 4 (3), pp. 197-207.

5. Frazja, M. \& Khademi, M. (2012). The relationship between trasformational and interactive leadership styles and organizational change readiness, New ideas in Educational Sciences, 6 (4), pp. 49-70.

6. Geijsel, F., Sleeger, S.P., Leithwood, K. \& Jantzi, D. (2003). Transformational leadership effect on teacher's Commitment and effort toward school reform, Journal of Educational Administration, 41 (3), pp. 228-256.

7. Gill, R. (2010). Theory \& practice of leadership. British, London, Sage Publication.

8. Holloway, S.D. (2015). Leading and Engaging Sustainable Change: Achieving Organizational Transformation through the Transformative Methodologies of the Change Acceleration Process and Lean Six Sigma (Doctoral dissertation, Cardinal Stritch University).

9. Isett, K.R., Glied, S.A.M., Sparer, M.S. \& Brown, L.D. (2012). When change becomes transformation: A case study of change management in Medicaid offices in New York City, Public Management Review, 15 (1), pp. 1-17.

10. Jalilian, H., Moradi, M. \& Kamaei, H. (2010). Transformational leadership and creativity of employees, Police Human Resources, 7 (32), pp. 59-72.

11. Juechter, W.M., Fisher, C. \& Alford, R.J. (1998). Five conditions for high-performance cultures, Training And Development-Alexandria-American Society For Training And Development, 52, pp. 63-68.

12. Kickert, W.J.M. (2010). Managing emergent and complex change: The case of the Dutchagencification, International Review of Administrative Sciences, 76 (3), 489 p.

13. Linstone, H.A. \& Mitroff, I.I. (1994). The challenge of the 21st century: Managing technology and ourselves in a shrinking world. SUNY Press.

14. Malhotra, N. \& Hinings, C.B. (2015). Unpacking continuity and change as a process of organizational transformation, Long Range Planning, 48 (1), pp. 1-22.

15. Mousavi, S.-A. (2005). Organizational change and transformation, Correcting and training, 43, pp. 44-46.

16. Nabavi, A., Hasanzadeh, A. \& Alameh, S. (2013). Effect of bureaucratic characteristics on work alleniation of employees, Social problems of Iran, 4 (2), pp. 131-154.

17. Pawar, B.S. (2003). Central Conceptual issues, in transformational, Leadership Research \& organization Development Journal, 24 (7), pp. 397-406.

18. Pearce, C.L., Sims Jr, H.P. Cox, J.F. Ball, Go, Schnell, E. (2003). Transactors, Transformers and beyond, Journal of inanagement Development, 22 (4), pp. 273-278.

19. Raeeisi, A. (2006). Change management in state and police organizations, Police knowledge, 8 (2), pp. 99-117.

20. Rahmanseresht, H. \& Moghaddam, A. (2007). The role of subjective models in organizational change process, Management Knowledge, 78, pp. 3-24.

21. Robbins, S.P. (2002). Organizational Behavior, $9^{\text {th }}$ edition, Prentice-Hall, Inc.

22. Russ, T.L. (2008). Communicating change: A review and critical analysis ofprogrammatic and participatory implemen- 
tation approach, Journal of ChangeManagement, 8 (3-4), pp. 199-211.

23. Shamir, B., House, R.J. \& Arthur, M.B. (1993). The motivational effects of charismatic leadership: A self-concept based theory, Organization science, 4 (4), pp. 577-594.

24. Soltani, I. (2005). The role of public relations in strategic leadership of organizational change, 8th art, 38, pp. 19-23.

25. Thistle, B.M. \& Molinaro, V. (2016). Driving Organizational Transformation Through Strong Leadership Accountability: It's Time For HR Leaders to Step Up, People and Strategy, 39 (3), pp. 28-31.

26. Tseng, S.H. (2010). The correlation between organizational culture and behavior modification on corporate performance, Journal of knowledge management, 14 (2), pp. 269-284.

27. Van der Voet, J. (2014). The effectiveness and specificity of change management in a public organization: Transformational leadership and a bureaucratic organizational structure, European Management Journal, 32 (3), pp. 373-382.

28. Van der Voet, J., Kuipers, B.S. \& Groeneveld, S. (2016). Implementing Change in Public Organizations: The relationship between leadership and affective commitment to change in a public sector context, Public Management Review, 18 (6), pp. 842-865. 